\title{
DOŚWIADCZENIE ROZŁĄKI EMIGRACYJNEJ A RELACJE RODZINNE. SPOSÓB POSTRZEGANIA EMIGRANTÓW ZAROBKOWYCH PRZEZ ICH DZIECI
}

\begin{abstract}
Abstrakt. Badania zawierały charakterystyki członków najbliższej rodziny dokonywane przez dzieci emigrantów zarobkowych. W badaniach za respondentów, określonych mianem dzieci emigrantów zarobkowych, uznano jednostki, które w okresie dorastania (wczesnego lub późnego) doświadczały rozłąki z rodzicami, spowodowanej wyjazdami zarobkowymi jednego lub obojga rodziców do pracy za granicę na terenie Unii Europejskiej. W badaniach wykorzystano metodę biograficzną. Łącznie respondentami były 84 osoby, a dane pozyskane w wywiadach uznano za wysoce nasycone o dużym stopniu zróżnicowania treści. Z prowadzonych badań wynika, że wraz $\mathrm{z}$ upływem czasu dla wszystkich członków rodziny poza emigrantem jego przyjazd do domu staje się wydarzeniem powszednim. Ma to jednoznaczne konsekwencje - widoczne w relacjach między członkami rodziny - które zostały zaprezentowane w artykule. Ze względu na wielowątkowy, szeroki i szczególnie emocjonalny materiał, jaki otrzymano w badaniach, w niniejszej publikacji zamieszczono wiele egzemplifikacji indywidualnych interpretacji własnej sytuacji życiowej dzieci emigrantów.
\end{abstract}

Słowa kluczowe: doświadczenie rozłąki, emigracja zarobkowa, rodzina emigracyjna, młodzież.

\section{Wprowadzenie}

W obliczu wielu określeń odnośnie do rodzin, w których funkcjonowanie wpisana jest migracja rodziców, pojawiają się spory dotyczące wyboru jak najtrafniejszego, a jednoczenie najmniej stygmatyzującego terminu. Wioleta Danilewicz (2006) rodzinę czasowo niepełną określa terminem „rodzina rozłączona ze względu na przestrzenne rozdzielenie jej członków". Natomiast rodziny roz-

* Dr, Zakład Badań Problemów Społecznych i Pracy Socjalnej, Wydział Socjologii, Uniwersytet im. Adama Mickiewicza w Poznaniu, ul. Szamarzewskiego 89, budynek C, 60-568 Poznań, e-mail: natasza.doiczman@amu.edu.pl 
łączone, których członkowie doświadczają rozłąki z powodu migracji zarobkowej obojga rodziców, nazywa migracyjnymi. Jak zauważa Danilewicz (2010), termin „rodzina migracyjna” może wydawać się mało precyzyjny chociażby ze względu na fakt, że skłania do traktowania rodzin migracyjnych jako takich, w których emigrantami są również dzieci. Inna definicja wskazuje, że rodzina migrancka funkcjonuje w co najmniej dwóch domach i państwach (Kawczyńska-Butrym, Kruk 2015). Zatem w ujęciu proponowanym przez Danilewicz rodzinę rozłączoną przestrzennie charakteryzuje struktura, w której jedno z rodziców wychowuje dzieci przy ograniczonym udziale drugiego rodzica. Natomiast rodziną migracyjną jest ta, w której oboje rodzice pracują poza granicami kraju ${ }^{1}$. Danilewicz dokonała podziału rodzin rozłączonych przestrzennie ze względu na różne kryteria definicyjne (Danilewicz 2008).

Poprzez dogłębne badania starano się ukazać jak najspójniejszą historię życia ludzi, których codzienność zdeterminowana jest przez doświadczenie rozłąki emigracyjnej. Celem analiz było przełamanie dotychczasowego stereotypu eurosieroctwa ${ }^{2}$ i spojrzenie na problem bez osądzającej perspektywy, przy ukazaniu doświadczeń tych, o których mówi się wiele, ale wciąż słyszy się ich rzadko3. Wykorzystany w niniejszym artykule materiał empiryczny stanowi jedynie wybrany fragment zdecydowanie szerszych badań, które były podstawą dysertacji doktorskiej zatytułowanej Doświadczenie ,eurosieroctwa” w biografiach mtodzieży $z$ rodzin migracyjnych ${ }^{4}$. Celem artykułu jest ukazanie sposobu radzenia sobie przez młodzież z rodzin migracyjnych z wyzwaniami, trudnościami w życiu codziennym, sposobu rozumienia sytuacji rodzinnej, dawania sobie rady z wymaganiami otoczenia społecznego. Artykuł miał stanowić odpowiedź na pytania:

${ }^{1} \mathrm{~W}$ niniejszym artykule termin „rodzina rozłączona” odnosić się będzie również do rodzin w sytuacji, gdy dwoje rodziców migruje i pozostawia dzieci w kraju pochodzenia. Wobec tego terminy „rodzina rozłączona” i „rodzina migracyjna” traktowane są synonimicznie.

${ }^{2}$ Wyjątkowo dużym zainteresowaniem badaczy cieszą się konsekwencje funkcjonowania rodzin migracyjnych, ze szczególnym naciskiem na zagrożenia dotykające dzieci. Sylwia Urbańska (2010) opisywała ten rodzaj zainteresowania jako wybuch paniki społecznej w związku z retradycjonalizacją ról rodzicielskich i wskazywała na narodziny nowego dyskursu eksperckiego, zorientowanego wokół eurosieroctwa.

${ }^{3}$ Małgorzata Ślusarczyk (2019) wskazuje, że zainteresowanie rodzinami transnarodowymi można podzielić na obszar dotyczący wyzwań i trudności, z jakimi zmagają się członkowie tego rodzaju rodzin (w tym: problemy rodzin transnarodowych, dyskurs o rodzicielstwie w rozłące, problemy dzieci, dyskurs o eurosieroctwie, rozpad związku, opieka nad starzejącymi się rodzicami pozostającymi w Polsce), oraz obszar skoncentrowany na dynamice życia rodzin transnarodowych, kształtowaniu poczucia przynależności i tożsamości narodowej i etnicznej w kontekście transnarodowym.

${ }^{4}$ Ze względu na przedmiot badań w podjętej analizie korzystałam z metod jakościowych. Wybór problematyki subiektywnych ludzkich doświadczeń sprawił, że artykuł sytuuje się w nurcie interpretatywnym, zakładającym wniknięcie w rzeczywistość społeczną ludzi w sposób szczególny - odnoszącym się do ich doświadczeń, nadawania znaczenia tym doświadczeniom, reprodukowania nabywanych umiejętności w obszarze doświadczeń oraz podtrzymywania wytwarzanego swoistego ładu. 
- Jakie miejsce w opowieściach narratorów zajmują rodzice?

- Jaka jest rola rodziców w doświadczaniu codzienności przez ich dzieci?

- W jaki sposób badani charakteryzują emigrujących zarobkowo rodziców?

Prowadzone analizy zawierały m.in. charakterystyki członków najbliższej rodziny dokonywane przez dzieci emigrantów zarobkowych. W badaniach za respondentów ${ }^{5}$, których określono mianem dzieci ${ }^{6} \mathrm{z}$ rodzin migracyjnych, uznano jednostki, które w okresie dorastania (wczesnego lub późnego) (Oleszkowicz, Senejko 2012), czyli w okresie między 12. a 22. rokiem życia, doświadczały przynajmniej dwukrotnej rozłąki z rodzicami, spowodowanej wyjazdami zarobkowymi jednego lub obojga rodziców do pracy za granicę na terenie Unii Europejskiej. Warunkiem udziału w badaniu było spełnienie kryterium emigracji zarobkowej rodziców, która trwała przynajmniej od dwóch lat. Uznano, że dwa zamknięte, pełne cykle roku kalendarzowego obejmujące dwukrotnie dni świąteczne i codzienne wiążą się z elementami rutyny i powtarzalności w funkcjonowaniu rodziny migracyjnej. Ponadto przeprowadzono wywiady również z członkami rodzin narratorów: pozostającymi w kraju rodzicami, rodzicami migrantami oraz rodzeństwem adolescentów. Wśród badanych znalazła się nie tylko młodzież, która aktualnie uczy się w szkołach ponadpodstawowych, ale również osoby będące obecnie w okresie wczesnej dorosłości, które miały za sobą wieloletnie doświadczenia rozłąki z rodzicami, także w okresie dzieciństwa ${ }^{7}$ i dorastania. Wprowadzenie takich narratorów do grupy badanych wzbogaciło materiał o historie opowiadane z dłuższej perspektywy czasu. Pozwoliło to na dokładne poznanie i ukazanie pełnego portretu doświadczeń osób z rodzin emigrantów zarobkowych, uwzględniające przy tym ich dalsze losy.

Jak wynika z przeprowadzonych badań, większość respondentów to osoby charakteryzujące się określonym statusem społecznym, zwykle o słabym bądź przeciętnym zapleczu materialnym, których rodzice posiadali wykształcenie podstawowe, zawodowe bądź średnie. Przyczyną emigracji rodziców była zła sytuacja ekonomiczna rodziny. Wyjazd zarobkowy za granicę postrzegany był przez członków rodziny migracyjnej jako tymczasowa próba poradzenia sobie z problemami finansowymi. Przed wyjazdem za granicę większość rodziców posiadała mało satysfakcjonującą i źle płatną pracę. Najczęściej to ojcowie podejmowali decyzję o wyjeździe, pozostawiając żony wraz z dziećmi w kraju pochodzenia. Wielu badanych oprócz wieloletniej rozłąki z ojcem doświadczało także epizodów

${ }^{5}$ Ze względu na korzystanie z metody biograficznej respondenci w niniejszym artykule określani są także mianem narratorów.

${ }^{6}$ Termin „dziecko” („dziecko emigranta”) w niniejszej publikacji używany jest w odniesieniu do pełnionej roli, nie do okresu rozwojowego, w którym aktualnie znajduje się jednostka.

${ }^{7}$ K. Ornacka (2013: 73) wskazuje, że „Mając na uwadze perspektywę dziecka, można powiedzieć, że dzieciństwo jest okresem przejściowym. Z punktu widzenia społeczeństwa stanowi ono stałą kategorię strukturalną, a to oznacza, że dzieciństwo nie ulega zanikowi, lecz jest poddawane rozmaitym przeobrażeniom czy to historycznym, czy kulturowym". 
rozłąki z matką, która podejmowała tymczasową pracę za granicą, najczęściej mającą charakter sezonowy. Ojcowie migranci pracowali zazwyczaj jako budowlańcy i kierowcy, a także podejmowali się zajęć z zakresu ogrodnictwa i rolnictwa. Emigrujące matki najczęściej opiekowały się osobami starszymi i chorymi, sprzątały, a także wykonywały prace ogrodnicze. Średni czas rozłąki emigracyjnej narratorów z rodzicem wynosił 16 lat. Najkrócej sytuacja emigracji w rodzinie trwała 4 lata, a najdłużej (w przypadku dorosłego badanego doświadczającego rozłąki z rodzicem w przeszłości) - 27 lat. Najczęściej osobami, z którymi badani pozostawali na czas rozłąki z rodzicem migrantem, byli drugi rodzic i/lub rodzeństwo, a najrzadziej babcie.

Ze względu na biograficzny charakter prowadzonych badań do udziału w wywiadach zostały zakwalifikowane osoby, w których biografię w sposób znaczący i trwały, ich zdaniem, wpisała się poakcesyjna migracja rodziców trwająca przynajmniej od dwóch lat. W podjętych badaniach dobór próby miał charakter celowy. Kryterium rekrutacji do udziału w badaniu stanowił wiek badanych podczas emigracji rodziców (okres dorastania), co najmniej dwukrotna (trwająca od dwóch lat) rozłąka z rodzicami, poakcesyjna migracja zarobkowa jednego lub obojga rodziców. Łącznie respondentami były 84 osoby, a dane pozyskane w wywiadach uznano za wysoce nasycone o dużym stopniu zróżnicowania treści. Autobiograficzny wywiad narracyjny stanowił jeden ze sposobów pozyskiwania bogatego materiału badawczego. Wszystkie wywiady: kwestionariuszowe, wywiady swobodne oraz narracyjne przeprowadzono samodzielnie, aby przekaz o doświadczeniach biograficznych związanych z migracją był jak najszerszy i aby nie utracić pozawerbalnej, silnie emocjonalnej strony przekazu, która najpełniej daje się odczytać w bezpośredniej relacji z badanymi. Po etapie prowadzenia badań i sporządzeniu transkrypcji otrzymano obszerny wydruk liczący 1373 strony dosłownych wypowiedzi znormalizowanego tekstu, który analizowany był przy użyciu programu MAXQDA. Początkowo utworzony został klucz kategoryzacyjny, który umożliwił wstępne uporządkowanie materiału (linijka po linijce), a następnie kodowanie materiału na podstawie utworzonych kategorii istotnych z perspektywy celu i przedmiotu badań. Zadanie to było bardzo wymagające, ale dało szansę na pozyskanie wysokiego jakościowo i ogromnego ilościowo materiału badawczego.

\section{Sposób postrzegania rodzica przez dzieci emigrantów zarobkowych}

W przypadku badanych, którzy mimo rozłąki pozostawali w dobrych relacjach z rodzicami migrantami, zwłaszcza gdy ich sytuacja materialna uległa poprawie dzięki pieniądzom zarobionym poza granicami kraju, osoba emigranta była postrzegana w kategoriach powodzenia. Umiejętność posługiwania się językiem obcym, praca w innym kontekście społeczno-kulturowym były powodem, dla którego rodzic migrant uważany był za osobę odnoszącą sukcesy. Badania 
wskazują, że pracujący za granicą rodzice są przez niektóre dzieci gloryfikowani. Im więcej posiadają one dzięki zarobionym pieniądzom dóbr materialnych i odczuwają korzyści w życiu codziennym, a dodatkowo relacje rodzica z dzieckiem są zadowalające, tym bardziej rodzic był doceniany. Odwrotnie do bezrobocia, które powoduje utratę pozycji autorytetu w rodzinie i sprzyja narastaniu konfliktów (Krajewska 2014). Z badań wynika, że dzieci często przejmowały język rodziców, ich narracje, i charakteryzowały emigrację i emigranta tak, jak było to ujmowane w przekazach rodzica. Poniższe wypowiedzi są wybranymi przykładami docenienia roli emigranta i uznawania rodzica pracującego za granicą za osobę odnoszącą sukcesy:

Myślę, że oboje odnosza sukcesy. Dla mnie to jest coś jakby wielkiego, że sa poza granicami kraju i że potrafią się obstugiwać tym językiem i w ogóle. To jest dla mnie coś wielkiego ogólnie (A.21.K).

Wielu badanych, których łączyły niezadowalające relacje z rodzicami migrantami, uważało rodziców za osoby nieporadne życiowo, tzw. nieudaczników. Narratorzy próbowali usprawiedliwić swoje przekonania. Czuli, że nie powinni wypowiadać tego rodzaju komentarzy. Bierność zawodowa, niechęć wobec zmian lub nieumiejętność radzenia sobie z trudami i przystosowaniem się do panujących zasad były dla badanych powodem do postrzegania rodzica jako nieudacznika. Młodzi ludzie przyznawali, że nigdy nie wypowiedzieliby tych słów w obecności członków rodziny, a jedyną sytuacją, w której są skłonni tę opinię wyrazić, jest moment wywiadu, w którym z wielką ostrożnością i namysłem używali tego określenia:

Nieudacznik to jest za duże stowo, aczkolwiek [przyp. ND-Ł: nazwałbym tak] też tatę, ponieważ swojej pracy nie znosi, a dalej w niej siedzi (P.4.K).

Myśle , że czasami [przyp. ND-Ł: nazwałbym nieudacznikiem] mojego tate, z racji tego, że on nigdy nie potrafit żadnej pracy utrzymać, przynajmniej $w$ tamtym czasie. Nie potrafit żadnej pracy utrzymać dtużej, bo właściwie to też jest taki jego charakter, który nie pozwala mu siedzieć w biurze czy gdziekolwiek indziej. On nie lubi takiej pracy, gdzie ktoś mu każe siedzieć przez osiem godzin w jednym miejscu. Więc on się $w$ takiej pracy $w$ ogóle nie odnajdowat, przez to też dtugo jej nie utrzymywat. Wydaje mi się, że to też tak przez to. On też miat dużo takich pomystów na biznes, których nie potrafił ani rozwinać, ani w odpowiedni sposób zakończyć i bardzo często się kończyło tak, że on ma pomyst, a moja mama musi jakby to naprawiać (P.11.K).

Emigracja zarobkowa, na którą decydowali się rodzice po wielu nieudanych próbach zatrudnienia w Polsce, obserwowana przez dzieci, była przez nie postrzegana jako dowód niezaradności życiowej. Wyjazd z kraju był wówczas synonimem ucieczki, tchórzostwa i braku pomysłu na wykorzystanie własnych możliwości. Zdania te narratorzy zwykle wygłaszali z dużą ostrożnością i próbą wyważenia słów, tak by nie uraziły rodzica ${ }^{8}$ :

${ }^{8}$ Odpowiadając na te pytania, upewniali się, czy wywiad na pewno jest przeprowadzany w atmosferze poufności. 
Może nie tyle za nieudacznika $i$ w ogóle, ale uważam że $w$ sumie... Jednak mimo wszystko... mama po skończeniu szkoły $i$ tak dalej, ona nawet nie szukała przez pewien czas w ogóle pracy tutaj i zaczęła tylko to studio swoje mieć. Miała je rok, zamknęła je. Później miała je tak jakby $w$ domu i jeździła do klientek, one do niej, ale żeby podjać taka normalna pracę, to tak nigdy się do tego jakoś nie brała i siedziała $w$ domu. Teraz wyjechała $i$ wraca co pewien czas (A.2.K).

Dla badanych, którzy z jednej strony odczuwali liczne negatywne konsekwencje rozłąki, ale z drugiej strony byli świadomi, że niektóre rzeczy zawdzięczają wyłącznie migracji rodzica, trudna była jednoznaczna ocena opiekunów. Stawianie przez rodziców korzyści materialnych ponad wartościami rodzinnymi było dla młodzieży świadectwem ich nieporadności życiowej. Pozbawiony pasji i satysfakcji życiowej rodzic, który poświęcił życie rodzinne w imię zarabianych za granicą pieniędzy, to dla badanych życiowy nieudacznik. Opinia ta generalizowana była także na rodzica pozostającego w kraju, który poprzez brak sprzeciwu wobec tej sytuacji potwierdzał swoją bierność wobec rozłąki rodziny. Poniższa wypowiedź jest przykładem opinii, które pojawiały się w badaniach dość często:

Wiesz, no bo z jednej strony ja trochę tak postrzegatam chyba oboje moich rodziców, wiesz [przyp. ND-Ł: jako nieudaczników]? W takim sensie, że nie robia nic takiego, co by im przynosiło satysfakcję, bo mama najpierw kochała robić zdjęcia, później przestała to robić i już tego nie robiła. I postrzegałam ja jako osobę pozbawiona pasji. Tak samo tatę. Tata ciężko pracowat, nie byto go z nami i pat... tak patrzac na osoby gdzieś tam z mojego otoczenia, których rodzice mieli firmy, którzy pracowali w jakimś takim normalnym rytmie... [...] A z drugiej to, że wybudowali piękny dom i spetnili swoje marzenie, które... no w sumie nie wiem, czy byto do końca tym, czego oczekiwali, też byt, powiedzmy, jakiś sukces, ale dla mnie to, czym to byto okupione... Wiesz... to nie byto tego po prostu warte. [...] Czasami... oni się bardzo różnie wypowiadają na ten temat, bo czasami to tak, że maja taki piękny dom $i$ wogóle, że super... Ale częściej chyba jednak trochę żałują tego, że to się nie potoczyło w inna stronę. Że jednak tyle lat tej rozłąki, tego życia właściwie osobno, negatywnych emocji... No i tego, że... że tak naprawdę tyle czasu byli osobno, że nawet jak tata przyjeżḋat, to właśnie przez to, że to byto zaburzenie jakiegoś rytmu, no to byto dużo konfliktów, dużo napięcia i to nie było, to nie było, nie było, nie czerpali przyjemności z tego, że byli razem w tym czasie i z tego, że byliśmy wszyscy razem $w$ ogóle. Więc myślę, że oni też patrzac na to z perspektywy czasu, no, uznaja to... gdzieś tam jednak było okupione zbyt dużymi negatywnymi konsekwencjami, nie? (P.22.K).

Dla dzieci emigrantów kluczowa w ocenie rodzica była kwestia tego, że opiekunowie nie potrafili oszacować ponoszonych przez wszystkich członków rodziny kosztów w związku z realizowanym życiem na odległość.

\section{Wspólobecność a zaufanie i troska w rodzinie emigrantów zarobkowych}

Codzienne kontakty, posługując się językiem Goffmana (2008: 21) - wspótobecność - w codziennym funkcjonowaniu są warunkiem, aby osoba została uznana przez młodych ludzi za godną zaufania, taką, do której udają się, by otrzymać 
wsparcie. Dorosłe osoby, które w okresie dorastania przeżywały rozłąkę z migrującymi rodzicami, relacjonowały podobne doświadczenia jak respondenci, którzy doświadczają rozłąki obecnie, w okresie adolescencji. Rodzic emigrant, nieorientujący się w aktualnej sytuacji dziecka, nie był osobą, którą proszono o wsparcie. Nawet jeśli dzieci emigrantów opisywały rozłąkę z rodzicami jako w zasadzie pozbawioną negatywnych konsekwencji, to jednak przebywanie w rozdzieleniu przestrzennym z rodzicem pracującym za granicą sprawiało, że korzystały one zwykle z pocieszenia osób będących blisko fizycznie i mających podobne poczucie upływającego czasu:

No to $w$ domu, najbliżsi, bracia i mama. Tylko to grono (A.19.M).

On [przyp. ND-Ł: ojciec migrant] dalej jest zatrzymany na tym etapie, że nic się nie zmienia, więc ciężko jest wytlumaczyć komuś, że ma się problem, skoro jak byt ostatnio, to tego problemu nie byto (P.4.K).

W historiach badanych pojawiała się również dysproporcja troski i odwrócenie ról w kwestii opiekuńczości. Badani pytani o otaczanie ich troską przez najbliższą rodzinę stwierdzali, że to oni byli głównym źródłem opiekuńczości w stosunku do rodzica migranta. Osoby badane w swoich historiach życia jawiły się jako bardziej dojrzałe aniżeli ich pracujący za granicą rodzice. Dzieci emigrantów stawały się wówczas źródłem wsparcia emocjonalnego, jednocześnie czując, że rodzic jest skupiony głównie na sprawach funkcjonowania w społeczeństwie przyjmującym, a nie na problemach swojego dziecka. Jak wynika z analiz, dzieci w obliczu rozłąki stawały się osobami, którym migrant zwierzał się ze swoich trudności i problemów, na co jednoznacznie wskazuje poniższa wypowiedź:

Jakby ten jej wyjazd, jakby to tez była dla niej jakaś trudna sytuacja, tak? I też ona dopiero się uczyła niemieckiego, więc to była dla niej też sytuacja trudna i właściwie często właśnie na początku to było tak, że gdzieś ona, wiesz, jakby zwierzała się z jakichś swoich problemów czy trudności i jakby zajmowała ta większa część tej przestrzeni, a tak w sumie... okej, wiesz, jak ja miałam jej coś do powiedzenia, to jej mówiłam czy zwierzałam się, czy skarżyłam na babcię, ale jednak, no, myśle, że bardziej była jednak zaabsorbowana swoimi problemami niż tym, co się dzieje tutaj (P.6.K).

Poczucie troski doświadczanej ze strony rodziców ulegało zmianie wraz z dorastaniem dzieci. Badani, którzy przez cały okres dorastania doświadczali rozłąki, a zbliżali się do wejścia w dorosłość, znacznie lepiej z perspektywy czasu oceniali poziom troski i zrozumienia, oferowanych im przez rodziców - mimo ich nieobecności. Upływający czas, uporządkowanie i zrozumienie oraz włączenie doświadczeń we własną biografię sprawiało, że intencje i zachowania rodziców były przez badanych traktowane bardziej pobłażliwie niż jeszcze kilka lat wcześniej. Wśród adolescentów pojawiały się wypowiedzi o przedkładaniu przez rodziców pracy nad życie rodzinne i opiekę nad dziećmi. Jedna z wypowiedzi wskazuje na emocje z tym związane: 
Mimo że ja miałam czasami myśli, że nic nie znaczę dla rodziców, że praca jest dla nich najważniejsza, to, szczególnie z perspektywy czasu, ja wiem, że to ja jestem najważniejsza dla tych rodziców $i$ w ogień by polecieli za mna. [...] Szczególnie tata, jak byłam w gimnazjum, to wtedy na tym etapie bardzo negatywnie na tate patrzylam $i$ wolatam, żeby po prostu siedziat za granica i nie wracat (A.12.K).

Szczególnie zaradne i zorganizowane dzieci emigrantów traktowane były przez rodziców jak dorośli, odpowiedzialni za siebie członkowie rodziny. W związku z tym poziom troski i opieki był wobec nich ograniczany adekwatnie do dorosłego sposobu funkcjonowania. Badani opowiadali o tendencyjnych pytaniach ze strony rodziców, mających stwarzać pozory opieki. Do zaradnego i dojrzałego funkcjonowania dzieci przyzwyczajeni byli również rodzice pozostający w kraju, którzy w związku z obserwowaniem prawie dorostych potomków byli, ich zdaniem, zwolnieni z troski i opieki nad nimi. Wiele wypowiedzi narratorów odnosiło się do rozczarowania wynikającego z niespełnionych oczekiwań i konfrontacji z rzeczywistością swoich wyobrażeń na temat troski i zainteresowania.

Ja oczekiwałem tego, że ktoś będzie się interesowat tym, czy ja mam kolegów i koleżanki, jakich mam kolegów i koleżanki, jak oni się nazywaja, czy ja się uczę dobrze w szkole, tego, żeby ktoś otworzyt mi zeszyt i zobaczyl, czy ja mam napisane, że trzeba zrobić zadanie domowe, czy je zrobitem (P.8.M).

Nie czułam [przyp. ND-Ł: troski ze strony rodziców]. Tak jak mówię, to byty takie pytania ze strony taty: „Jak w szkole?” [...]. A mama niby była, ale mama też miała swoje jakieś problemy i ja ja też tak chciałam trochę odciązyć i mam wrażenie, że ona się nauczyła tego, że ja sobie radzę $i$ ż ja sobie jestem już dorosła, że szybko wydoroślałam, to nie musiała się właśnie pytać. To jednak byt bład, bo dziecko potrzebuje, dopiero teraz widzę, ze swojego czasu, że krzyczałam, że jej nie powiem, a miałam te piętnaście lat, to jednak chciałam, żeby ze mna usiadła, porozmawiała, a to widać, że zabrakło gdzieś tam (P.20.K).

\section{Charakterystyka rodziców dokonywana przez dzieci emigrantów zarobkowych}

Ze względu na przedmiot i cel badań szczególnie ważna była kwestia oceny i charakterystyki rodziców dokonanych przez dzieci migrantów. Badani, których rodzice pracowali od wielu lat za granica, mieli trudność ze scharakteryzowaniem swoich opiekunów, z którymi na co dzień żyją w rozdzieleniu przestrzennym. Za cechę definiującą osobę rodzica uznawali pracę za granicą. Rodziców postrzegali w związku z tym jako pracowitych, ale często mieli problem z opisaniem, w czym ta cecha się przejawia, czym konkretnie zajmuje się rodzic, jaka jest specyfika jego pracy. Rzadko w sposobie opisywania pojawiały się określenia posiadające ładunek emocjonalny, takie jak miłość, troska, opiekuńczość. Tych słów używali zwykle do charakterystyki rodzica pozostającego z dziećmi w kraju pochodzenia. 
Rozłąka sprawiała, że badani z trudnością opowiadali o rodzicu migrancie. Towarzyszyło im przekonanie, że nie znają w pełni rodzica pracującego za granicą. Określenia dotyczyły zwykle kwestii migracji i zarabianych pieniędzy. W wypowiedziach narratorów pojawiały się wątki, które świadczyły o chęci przekonania badacza, że rodzic mimo wszystko starał się kochać swych najbliższych. Tego typu sformułowanie podkreślało nastrój emocjonalny panujący w rodzinie, której członkowie sami siebie starali się przekonać, że czują się kochani i zaopiekowani, czego przejawem miało być otrzymywanie pieniędzy z zagranicy. Warto zaznaczyć, że znaczna część dochodów zarobionych za granicą przekazywana jest przez większość migrantów do rodzin w Polsce (Terelak, Kołodziejczak 2012). Szczególne w tej kwestii są poniższe wypowiedzi:

Mama jest dobra, kochana. Tata, tata pracuje za granica (A.9.K).

Moja mama na pewno jest troskliwa. Po prostu jest dobrym człowiekiem. Ambitna, nie wiem, co jeszcze mogę powiedzieć. Pracowita. Tata też jest pracowity. [milczenie] Z tata teraz gorzej troche, ale ja też wiem, że jest dobrym człowiekiem, ale z tata, powiem tak, że po prostu nie znamy się aż tak dobrze. Przez to, że go nie było tu $w$ domu, że teraz mamy gdzieś kontakt, wiem, że jest moim tata (A.12.K).

Narracje respondentów wskazywały na postrzeganie rodziców jako kochających dzięki oznakom materialnej troski. Badani podkreślali nieobecność rodzica, którą uważali za ważną podczas dokonywania ich charakterystyki:

[śmiech] Co o tacie powiedzieć? Tata. [zastanowienie] Nawet nie potrafię go opisać dokładnie. Takiego może i kochającego. W jakiś sposób kochat tę rodzinę, bo przesyłat im pieniądze zawsze wszystkie i starat się pomimo tego, że on miat kiedyś w przeszłości źle, to żebyśmy my może mieli trochę lepiej niż on. Po prostu takiego starajacego się nas kochać, może tak powiem: starającego się kochać (A.17.K).

Opiekuńcza, kochana [przyp. ND-Ł: mama]. Zaradny i pracowity [tata] (P.22.K).

Zapracowany. Mój tata tak naprawdę mało uczestniczyt w naszym życiu rodzinnym (P.18.K).

Wieloletnia, trwająca od okresu dzieciństwa rozłąka sprawiała, że dzieci emigrantów u kresu etapu dorastania stwierdzały, że relacje łączące ich z rodzicem zawsze były bardzo słabe, w związku z tym przypuszczają, że na tyle przywykły do tego doświadczenia, że wkrótce nie będą odczuwały ich braku. Mimo że w ich historiach pojawiają się wątki tęsknoty i silnych doświadczeń braku (zwykle ojca) sprzed kilku lat, opisując aktualną sytuację, badani chcą przekonać samych siebie, że rodzica emigranta nigdy wcześniej nie potrzebowali. Tego rodzaju sprzecznej oceny własnej historii i łączących ich z rodzicami więzi dokonywało wielu nastolatków:

Nigdy nie miałam tej więzi z moim ojcem i nigdy tego nie potrzebowałam (A.17.K).

Rodzice byli przez badanych postrzegani jako mniej dojrzali, mało zorganizowani i mniej odpowiedzialni w porównaniu do tego, jak dzieci opisywały same 
siebie. Przejęcie obowiązków związanych z wychowywaniem rodzeństwa i podejmowaniem kluczowych decyzji w rodzinie, a także większości obowiązków domowych skutkowało tym, że badani postrzegali siebie jako osoby dorosłe, dojrzałe, wyjątkowo dobrze zorganizowane, w przeciwieństwie do rodziców, którzy nie mogli znaleźć pracy w kraju i byli, ich zdaniem, zmuszeni do emigracji. Sposób charakteryzowania rodziców przez badanych świadczył o odwróceniu ról i zaburzeniach hierarchii w rodzinie. Szczególnie kwestię tę prezentują wypowiedzi:

[przyp. ND-Ł: Postrzegam matkę jako] nerwowa. [zastanowienie] Musi mieć zawsze rację. Trochę nieokrzesana. I chyba w sumie to tyle. Niepoukładana (A.2.K).

[przyp. ND-Ł: Ojciec] jest trochę chaotyczny i taki, że myśli czasem bardziej... Może nie gówniarsko, tylko na... tak jakby byt nastolatkiem bardziej ode mnie czasem. Że czasem nawet ja czy mój brat mówimy, że no, to jest trochę takie nieodpowiedzialne, żeby się uspokoit, ogarnąt nawet... (A.19.M).

Rozłąka powodująca reorganizację dotychczasowego sposobu funkcjonowania rodziny, zorientowanego wokół jednego gospodarstwa, w zdecydowanej większości prowadziła do napięcia emocjonalnego $\mathrm{w}$ atmosferze domowej. Wśród członków rodziny natomiast doświadczenia związane z emigracją były przyczyną swoistego stresu i reakcji emocjonalnych opisywanych jako wybuchowość, gwałtowność. Wielość obowiązków, które zaczęły spoczywać na pozostającym z dziećmi rodzicu, sprawiała, że był on postrzegany przez swoje potomstwo jako rygorystyczny, surowy, wydający rozkazy, w skrajnych przypadkach wyzyskujący. Cechą charakterystyczną dla rodziców pozostających w kraju z dziećmi była także ich wielozadaniowość. Kwestię częstego postrzegania rodziców przez dzieci jako nerwowych, surowych wyraźnie prezentują poniższe wypowiedzi:

Myślę, że [przyp. ND-Ł: mama jest] czuła, wielozadaniowa, może też zestresowana. A tata ... Jedyne, co mi przychodzi do głowy, to wybuchowy dosyć... Myśle, że też zestresowany (A.20.K).

Mama za surowa, zbyt rygorystyczna (A.5.M).

[Przyp. ND-Ł: Tata] nerwowy, nawet może czasami przechodzace $w$ agresywny $i$, jak by to powiedzieć, nie, że niegodny zaufania, tylko... Że nie można na nim polegać, o tak. Że jeżeli się go o coś prosi, to trzeba kilkanaście razy przypomnieć, żeby faktycznie to uzyskać (P.11.K).

Tabela 1. prezentuje zestawienie najczęściej pojawiających się w wypowiedziach respondentów przymiotników charakteryzujących rodziców. Cechy charakterystyczne dla rodziców pozostających $\mathrm{w}$ domu razem $\mathrm{z}$ dziećmi różniły się od tych przypisywanych migrantowi (por. Marczak 2016). Wymienione określenia stanowiące charakterystykę rodzica były odpowiedzią na jasną dyrektywę wymagającą podania cech rodzica pozostającego w kraju i rodzica migranta. 
Tabela 1. Najczęściej wymieniane przez dzieci cechy rodziców

\begin{tabular}{|c|c|}
\hline \multicolumn{2}{|c|}{ Charakterystyka rodzica } \\
\hline Pozostającego w kraju & Migranta \\
\hline \multicolumn{2}{|c|}{ Pozytywne określenia } \\
\hline Kochający & Pracowity \\
\hline Kochany & Zaradny \\
\hline Obecny & Starający się kochać rodzinę \\
\hline Dobry & Dobry \\
\hline Opiekuńczy & Dowcipny \\
\hline Sporadycznie wymieniane cechy: & Sporadycznie wymieniana cecha: \\
\hline Troskliwy & Rozweselający \\
\hline Czuły & \\
\hline \multicolumn{2}{|c|}{ Negatywne określenia } \\
\hline Nerwowy & Nieobecny \\
\hline Niedojrzały & Chaotyczny \\
\hline Wybuchowy & Niepoukładany \\
\hline Surowy & Nerwowy \\
\hline Rozżalony & Nieodpowiedzialny \\
\hline Sztywny & Niedojrzały \\
\hline Wściekły & Nie można na nim polegać \\
\hline Zagubiony & Zagubiony \\
\hline & Niechciany \\
\hline Sporadycznie wymieniane cechy: & Sporadycznie wymieniane cechy: \\
\hline Rozkazujący & Nieokrzesany \\
\hline Wyzyskujący/wykorzystujący & Wybuchowy \\
\hline Zestresowany & Zestresowany \\
\hline Sztywny & Agresywny \\
\hline Chłodny, zimny & Niegodny zaufania \\
\hline & Neurotyczny \\
\hline \multicolumn{2}{|c|}{ Ambiwalentne określenia } \\
\hline Podejmujący się wielu obowiązków/ & Trudny do opisania \\
\hline wielozadaniowy & Zapracowany \\
\hline Sporadycznie wymieniana cecha: & Sporadycznie wymieniane cechy: \\
\hline Rygorystyczny & Szalony \\
\hline & Energiczny \\
\hline
\end{tabular}

Źródło: Opracowanie własne.

Sposób postrzegania i ocena rodziców emigrantów dokonywana przez ich dzieci jest zmienna w czasie. Badania wskazują, że jednoznacznie negatywna ocena rodziców i odczuwany wobec nich żal mogą - przede wszystkim wraz 
z upływem czasu - zmienić się w pełną zrozumienia i obwiniającą siebie postawę dorosłego już dziecka emigranta. Mimo że w trakcie emigracji rodziców narratorzy mieli kilkanaście lat, to siebie uważają za winnych doświadczanej rozłąki. Biorą na siebie odpowiedzialność za brak umiejętności poradzenia sobie w społeczeństwie przyjmującym i powrót do kraju pochodzenia, bez rodziców, na co wskazuje m.in. poniższa wypowiedź:

Myślałam [przyp. ND-Ł: o matce], że jest okropna, że mnie zostawita. Tak naprawdę no to moja wina, bo ja chciałam wrócić do Polski, mogłam zostać z niq, ale też o mamie nie myślatam wtedy, że ona tak dlugo zostanie za granicą. [Przyp. ND-Ł: O ojcu], że jest najgorszym człowiekiem na świecie (P.14.K).

Doświadczenie rozłąki emigracyjnej determinowało sposób postrzegania rodziców przez dzieci. Poczucie opuszczenia pojawiające się zwykle wśród żon pozostających $\mathrm{w}$ kraju pochodzenia z dziećmi oraz wrażenie wyeliminowania z codziennego życia rodzinnego towarzyszące emigrantom sprawiały, że ich dzieci z perspektywy czasu postrzegały swoich rodziców głównie jako nieszczęśliwych z powodu emigracji, co wyraźnie prezentuje poniższa wypowiedź:

[Przyp. ND-Ł: Matka] wściekła, rozżalona, zagubiona, sztywna, chłodna, zimna... To nie byty dobre przymiotniki. [Przyp. ND-Ł: Ojciec pracujący za granicą] zagubiony, niechciany (P.21.K).

Badania wskazują, że postrzegana przez dzieci emigrantów relacja z pracującym za granicą rodzicem jest uważana za bardziej oddaloną, mniej emocjonalną przez sam fakt rozdzielenia przestrzennego w porównaniu do więzi z rodzicem pozostającym w kraju pochodzenia9. Jak wskazuje Marek Krajewski,

[...] relacje pomiędzy dzieckiem a rodzicem, młodymi a starymi, ze względu na włączenie każdego z podmiotów tego rodzaju stosunków w splątane sieci społeczne, przesiąknięte są ambiwalencjami, których rozwikłanie stanowi podstawowe zadanie tego rodzaju związków. Oznacza to z kolei, iż te ostatnie nie są oparte ani na solidarności, ani na konflikcie, ale na próbie poradzenia sobie ze sprzecznościami, które niesie za sobą bycie razem w splątanym, zmiennym świecie (Krajew ski 2012).

Relacja między dzieckiem a rodzicami pracującymi za granicą była określana jako dalsza, niezakotwiczona w codzienności. Związek z rodzicami pracującymi w innym kraju mógłby być zdaniem narratorów bliższy, gdyby rodzic mieszkał na co dzień w domu. Mimo podejmowanych wysiłków i regularnych rozmów za pośrednictwem telefonu i komputera rodzic migrant wydawał się młodzieży mało zorientowany w ich codzienności i aktualnych sprawach. Nawet poinformowanie

${ }^{9}$ Wypowiedzi badanych dotyczące emocjonalnego związku z rodzicem migrantem odnosiły się do pytania: Wyobraź sobie, że te okręgi to Ty i Twoja rodzina. Wybierz parę, która reprezentuje związek między Toba a Twoją najbliższa rodzina w tamtym czasie. Uzasadnij swój wybór. 
go o swoich doświadczeniach i osiągnięciach nie jest równoznaczne ze zrozumieniem sytuacji dziecka. Wiedza o wydarzeniach mających miejsce w jego życiu nie oznacza wspólnoty doświadczeń. W sposób wyjątkowy do kwestii relacji z migrantem nawiązuje wypowiedź:

Znaczy się, to jest bliska relacja, ale to nie była aż tak bardzo bliska relacja $i$ to nie było aż takie, żeby on [przyp. ND-Ł: ojciec] wszystko wiedziat, co się dzieje i w ogóle. Tam czasem mama mu musi tlumaczyć, że na przyktad teraz dostałem się do radia Meteor, to ja tlumaczę to mamie, a mama tlumaczy to tacie, a później tata mnie się pyta, bo i tak nic nie wie... [śmiech] Ale $w$ życiu rodzinnym stara się uczestniczyć po prostu, ale to nie jest tak, że... Przez to, że go... (A.1.M).

Codzienna rozłąka odpowiada za swego rodzaju odzwyczajanie się członków rodziny od siebie nawzajem. Dystans przestrzenny, a dodatkowo specyficzny sposób spędzania czasu podczas powrotów, zorientowany w dużej mierze na załatwianie różnego rodzaju zaległych spraw, powoduje oddalanie się od siebie rodzica migranta i dzieci. Wieloletnia rozłąka, której koniec nie był ściśle określony, sprawiała, że dzieci emigrantów zauważają coraz mniej wspólnych spraw, łączących je z rodzicem. W relacji dominuje poczucie braku, doświadczenie uciekającego czasu, trudnej do odzyskania straty. Nieobserwowanie zmian zachodzacych w dziecku i nieuczestniczenie rodzica w jego dorastaniu jest dla badanych kwestią wyłączającą opiekuna z codzienności i potęgującą izolowanie się od członków rodziny, na co wskazują poniższe wypowiedzi:

Wiele już nas też nie tączy (A.11.K).

Byt $i$ jest ogromny [przyp. ND-€: dystans w relacji z tata]. Zdecydowanie, zdecydowanie ogromny. My się dalej z tata bardzo źle dogadujemy. Pamiętam, że jak byłam mała, to ja byłam raczej córeczka tatusia. A gdzieś po drodze ja zaczęlam dorastać, mieć własne zdanie, a tata nie byt $w$ stanie tego zauważyć, więc potem wyjeżdzajac... No to wiadomo, każdy z nas byt na innym etapie, ja bytam bardzo wyszczekana, miatam bardzo, bardzo, bardzo wtasne zdanie. No $i$ to też bardzo nam się rozjechało (P.4.K).

Relacja z rodzicem migrantem określana jako daleka wpływała na postrzeganie w mniej satysfakcjonujący sposób relacji z całą najbliższą rodziną. Bliskość przestrzenna, częstotliwość kontaktów twarzą w twarz są dla dzieci emigrantów warunkiem zażyłych relacji. Jako bliższy związek uważają ten łączący ich z domownikami, nawet jeśli nie są spokrewnione z osobami współzamieszkującymi. Przykładem tej zależności jest sytuacja jednej z badanych, która jako bliższą traktuje relację z ojczymem, z którym mieszka od kilku lat, niż z matką emigrantką. Wypowiedzi dzieci emigrantów na temat postrzeganej bliskości w rodzinie świadczą o mieszaniu ról i zaburzeniu hierarchii oraz dominacji w rodzinie. Sposobem radzenia sobie z zauważonymi oznakami parentyfikacji jest dla młodzieży poczucie humoru. Na relacjonowane przez siebie sytuacje zastępowania młodszemu rodzeństwu matki badani reagowali śmiechem. Sytuacje życiowe, o których mówili respondenci, były jednak dość dramatyczne, ich przekaz nie współbrzmiał 
na poziomie emocjonalnym z wypowiadaną treścią komunikatu. Przykładem tego są wypowiedzi:

Nie mam takiego jakiegoś mega bliskiego kontaktu ani z siostra, Seweryn jest jeszcze za maty, żeby jakoś mega te zbudować, tyle tylko, że troche mu robię za mame i to $w$ sumie tyle. [...] on często na przykład się zapomni i powie do mnie „mamo”. [śmiech] Ja wtedy mówię mu, że mama jego jest za granica i przyjedzie (A.2.K).

Mama i ja [przyp. ND-Ł: opiekowałyśmy się moim bratem], ale teraz widzę z perspektywy czasu, że chyba ja więcej w sumie, mam wrażenie. Nie mówię tutaj o takim, że zawożenie na zajęcia, to té், bo też go odprowadzałam, ale myślę, że nawet takie jak mama siedziała, coś czytała sobie, to on siedział ze mna, więc myślę, że ja z nim więcej spędzałam czasu niż ona. Ja wiedziałam chyba więcej o jakichś kolegach ze szkoły, już kojarzyłam imiona, myślę, że ona chyba nawet nie do końca (P.20.K).

Sytuację mieszania ról w rodzinie dzieci starają się tłumaczyć i usprawiedliwiać, odciążając z winy rodziców. Narratorzy wyjaśniają, że trudne doświadczenia ich rodziców były powodem, dla którego z pełną świadomością musieli zastąpić ich wobec swojego rodzeństwa. Są to takie przeżycia jak m.in. wczesna śmierć opiekuna, konflikty w rodzinie. Wyraźnie wskazuje na tę kwestię poniższa wypowiedź badanego:

$Z$ tata jest bardziej... Nie rozmawiam. Tata też jest zamknięty $w$ sobie, on nie jest nauczony tego, żeby rozmawiać z kimś. [...] Sam fakt, że on nie miat w domu czegoś takiego, że rozmawiali u niego $w$ domu, właśnie on miat ciężko i przez to on nie jest tego nauczony, i mama nawet nam mówi, że tata nie miat tego i tak dalej, i ja jestem tego świadomy, przez to będę na przyktad się sta... Dlatego staratem się zawsze z braćmi rozmawiać i zastepować im czasem tatę. Tak, [przyp. ND-Ł: zastępuję ojca]. Miałem caty czas, cały czas takie było i jest $i$ ze wszystkim, nawet z uczeniem brata jeździć samochodem, to tata go uczyt, jak przyjechat czy coś, a nawet ja go tam raz uczyłem. Po prostu takie coś, że jak nie było taty, to ja go teraz, że mówię, co ma robić tam, nie wiem, ja nieraz w domu krzyczałem na niego, jak coś źle zrobit, $w$ ten sposób. No w sumie jestem starszy i musiałem mieć tę odpowiedzialność, bytem świadomy tego (A.19.M).

W rodzinach migracyjnych, w których rozłąka trwała wiele lat, a jej członkowie w bardzo emocjonalny sposób doświadczali rozstania, miało miejsce swoiste tworzenie indywidualnych przestrzeni funkcjonowania. Poszczególni członkowie rodziny także siebie określali jako indywidualne, mało powiązane ze sobą jednostki, które nie są ze sobą spójne, którym nie towarzyszy poczucie wspólnotowości. Stanowisko to było zgodne z rozumieniem przez Simmla indywidualizmu jako stanu, w którym ,[...] dana istota jest światem sama dla siebie, obracającym się wokół własnego ośrodka, w pewnej mierze zamkniętym i samowystarczalnym" (Simmel 2008: 412). Prezentują to jednoznacznie poniższe wypowiedzi:

Myśle, że generalnie jakby, sumując to wszystko razem, relacje, i matka, i babcia razem, no to jednak gdzieś każdy tak naprawdę żyt osobno i tak średnio w sumie byto jakieś poczucie... nie wiem, wspólnoty (P.6.K). 
Nie czułam, żebyśmy byli taka jednościa, taka rodzina... po prostu jednym zespołem, tylko każdy trochę sobie (P.22.K).

Ja się czułam jakby na zewnątrz tej rodziny (P.24.K).

Relacje z rodzicem pozostającym w kraju zmieniają się na przestrzeni czasu, od skrajnego niedoinformowania w sprawach rodzinnych, takich jak emigracja rodzica, po wyznaczanie dziecka jako powiernika wszelkich tajemnic i źródło wsparcia emocjonalnego w obliczu problemów. Natomiast relacja z rodzicem migrantem, mimo że bardzo silna emocjonalnie, określana jest jako powierzchowna, a tym samym nie zaspokaja potrzeb dziecka. Bez względu na częstotliwość powrotów i kontaktów z rodzicem pracującym za granicą narratorzy uważali, że przez większość czasu doświadczali ich braku:

Wydaje mi się, że tak gdzieś do dziewięciu, dziesięciu lat zupetnie dwa odrębne światy, a później prawie te złaczone. Później ta relacja [przyp. ND-Ł: z matką] się zrobiła bardzo intensywna, bardzo mocna i po prostu wtedy rzeczywiście nawiazaliśmy relacje, można powiedzieć. [...] Zawsze jak on [przyp. ND-Ł: ojciec] przyjeżdzat, to ja po prostu caly czas chcialem być w jego obecności [...], ale z drugiej strony przez większość czasu go nie było. I myśmy rozmawiali tylko przez telefon $i$... i nie wiem... Bo przez ten telefon nie bytem $w$ stanie z nim za dużo porozmawiać, to było wszystko taka wymiana takich powierzchownych informacji, ale emocjonalnie, jeśli bym miat tak powiedzié, emocjonalnie, tak po prostu się czuć związany, $w$ sensie takiej tęsknoty (P.8.M).

\section{Podsumowanie}

Badania wskazują, że rodzina oddziałuje na rozwój człowieka na wszystkich etapach życia, dając jednostce szansę na zdobywanie doświadczenia oraz przekazując jej określone wzory sposobu myślenia, odczuwania i wartości (Harwas -Napierała 2010). Izabela Szczy gielska (2013), odnosząc się do danych z raportu Banku Światowego Migration and Remittances Eastern Europe, podkreśla, że w żadnej ze sfer życia człowieka migracja nie pozostawia tak silnych konsekwencji jak w życiu rodzinnym. Nieobecność rodzica, który pracuje za granicą, jest dla dzieci powodem do odebrania mu przez członków rodziny możliwości ingerowania $\mathrm{w}$ ustalony porządek i rytm życia codziennego. Ponadto traktowanie emigracji jako porażki na rynku pracy w Polsce jest dla dzieci kolejną przyczyną, dla której udzielanie porad przez rodzica jest niezasadne i niewiarygodne. Sytuacja ta powoduje, że dłuższy pobyt migranta w domu rodzinnym, podczas którego stara się on wprowadzać zmiany i proponuje własne pomysły rozwiązywania problemów, zwykle kończy się nieporozumieniami i konfliktami z członkami rodziny. Z rozmów prowadzonych z rodzicami emigrantami wynika, że negowanie wszelkich podejmowanych przez nich inicjatyw, podważanie słuszności wypowiedzi utwierdza ich w przekonaniu, że są emocjonalnie obojętni dla bliskich pozostawionych w kraju pochodzenia. Wskazuje na to wypowiedź badanej: 
Wszystkie jego wady mnie bardziej denerwowały, że on mi mówi, że czegoś nie mam robić, gdzie to w ogóle do mnie nie docierało, bo ja miałam tam w granicach coś, tam w gimnazjum, no to powiedzmy, że trzynaście lat, wydawało mi się, że nie wiadomo jaka jestem dorosła, a on nie... Nie ma go pót roku i on mi będzie mówić, co ja mam robić, jak to mam robić?! Zreszta mu to do dzisiaj zostało, nie? I jade do domu, i wiem, że nastucham się tego, jak mam żyć, gdzie niestety, ale on też jakoś tam... no nie za bardzo to umiat wykorzystać, nie? Te wszystkie pomysty, które daje mi, tam, przełożyć na swoje życie (P.11.K).

Z perspektywy czasu dzieci emigrantów czują, że brak codziennych, rutynowych kontaktów i zachowań wpłynął destrukcyjnie na łączącą ich relację lub nie pozwolił na jej prawidłowe rozwinięcie. Nieobecność rodzica była dla dzieci emigrantów wyrazem tego, że funkcjonowanie rodziny zmieniło się pod wpływem wyjazdu zagranicznego, odbierając im - w ich przekonaniu - stabilizację i przewidywalność w życiu codziennym. Wielu badanych ma świadomość, że sytuacja rodzinna nie jest optymalna dla ich rozwoju i w związku z tym, aby chronić rodziców, unika tematów związanych z problemami dotyczącymi rozłąki i emigracji członka rodziny. $\mathrm{Z}$ przeprowadzonych badań wynika, że dla dzieci migrantów charakterystyczna była szczególna troska o rodziców, którą często przedkładały ponad własne potrzeby.

\section{Bibliografia}

Danilewicz W.T. (2006), Sytuacja życiowa dzieci w rodzinach migracyjnych, Wydawnictwo Uniwersyteckie Trans Humana, Białystok.

Danilewicz W.T. (2008), Rodzina migracyjna jako typ wspótczesnej rodziny w Polsce. Wybrane aspekty, [w:] A.W. Janke (red.), Wychowanie w rodzinie w teorii i praktyce. Rozwój pedagogicznej orientacji familiologicznej, Wydawnictwo Edukacyjne Akapit, Toruń.

Danilewicz W.T. (2010), Rodzina ponad granicami. Transnarodowe doświadczenia wspólnoty rodzinnej, Wydawnictwo Uniwersyteckie Trans Humana, Białystok.

Goffman E. (2008), Zachowanie w miejscach publicznych, przeł. O. Siara, Wydawnictwo Naukowe PWN, Warszawa.

Harwas-Napierała B. (2010), Rodzina w kontekście wspótczesnych zagrożeń, [w:] T. Rostowska, A. Jarmołowska (red.), Rozwojowe $i$ wychowawcze aspekty życia rodzinnego, Difin, Warszawa.

Kawczyńska-Butrym Z., Kruk M. (2015), Wsparcie społeczne dla rodzin migracyjnych w Polsce, [w:] I. Taranowicz, S. Grotowska (red.), Rodzina wobec wyzwań wspótczesności, Oficyna Wydawnicza Arboretum, Wrocław.

Krajewska A. (2014), Skutki bezrobocia i ubóstwa w życiu rodzin, „Journal of Modern Science”, nr 2, s. 63-76.

Krajewski M. (2012), Generacje rzeczy, „Ruch Prawniczy, Ekonomiczny i Socjologiczny”, t. LXXIV, z. 3, s. 91-103.

Marczak M. (2016), Percepcja cech osobowości osób migrujących a członkowie ich rodzin pozostawieni w domu rodzinnym pod opieka innych osób, [w:] Z. Kawczyńska-Butrym, E. Czapka (red.), Opieka nad dziećmi i starszymi rodzicami w rodzinach migrujacych kobiet, Wydawnictwo Polihymnia, Lublin. 
Oleszkowicz A., Senejko A. (2012), Dorastanie, [w:] J. Trempała (red.), Psychologia rozwoju człowieka, Wydawnictwo Naukowe PWN, Warszawa.

Ornacka K. (2013), Od socjologii do pracy socjalnej. Społeczny fenomen dzieciństwa, Wydawnictwo Uniwersytetu Jagiellońskiego, Kraków.

Simmel G. (2008), Pisma socjologiczne, przeł. M. Łukasiewicz, Oficyna Naukowa, Warszawa.

Szczygielska I. (2013), Migracje zarobkowe kobiet i ich wptyw na funkcjonowanie rodzin, Wydawnictwa Uniwersytetu Warszawskiego, Warszawa.

Ślusarczyk M. (2019), Transnarodowe życie rodzin. Na przyktadzie polskich migrantów w Norwegii, Wydawnictwo Uniwersytetu Jagiellońskiego, Kraków.

Terelak A., Kołodziejczak S. (2012), Zagraniczne emigracje zarobkowe mieszkańców województwa zachodniopomorskiego a regionalny rynek pracy. Studium socjologiczne, Przedsiębiorstwo Produkcyjno-Handlowe ZAPOL, Szczecin.

Urbańska S. (2010), ,, Cała Polska liczy eurosieroty”: panika moralna i płeć w wykluczeniu oraz stygmatyzacja rodzin migrantów, „Kultura i Społeczeństwo”, t. LIV, nr 3, s. 61-88.

\title{
THE EXPERIENCE OF SEPARATION AND FAMILY RELATIONS THE PERCEPTION OF EMIGRANTS BY THEIR CHILDREN
}

\begin{abstract}
The research included the characteristics of immediate family members made by the children of economic migrants. In the research, the respondents defined as children of economic migrants were defined as individuals who, in their adolescence (early or late), experienced separation from their parents, caused by one or both parents leaving for work abroad in the European Union. The biographical method was used in the research. There were 84 respondents in total, and the data obtained in the interviews was considered complete, with a high degree of content diversification. The conducted research shows that with the passage of time for all family members, except for the emigrant, his arrival home becomes a commonplace event. This has clear consequences visible in the relations between family members, which are presented in the article. Due to the multithreaded, broad and especially emotional material that was obtained in the research, this publication contains many examples of individual interpretations of their own life situation for the children of emigrants.

Keywords: the experience of separation, economic emigration, emigration family, youth.
\end{abstract}

